\title{
Conocarpus Mediated Improvement in Photosynthetic Pigments of Cicer arietinum Growing Under Copper Stress
}

\author{
Shabana Askari* and Hina Khurshid \\ Department of Botany, Jinnah University for Women, Karachi, Pakistan
}

\section{ABSTRACT}

Present work was planned to investigate the improvement in photosynthetic pigments of Cicer arietinum by Conocarpus lancifolius growing under copper stress. Conocarpus lancifolius was chosen as a biosorbent because it is abundantly and easily available plant of Province Sindh. It does not require so much efforts or money or even water to cultivate them, moreover, it is a fast grower. Plants were grown in randomized block design in triplicates. Each pot was supplied with $1 \mathrm{~kg}$ of soil, the control plants were supplied with distilled water only, experimental plants were supplied with different concentration of copper viz. 0, 25, 50, 75 and 100 ppm whereas treated plants were supplied with 5gm Conocarpus lancifolius leaf powder along with the different concentration of copper. Effect of Copper on Cicer arietinum and its biosorption by Conocarpus lancifolius was observed by the determination of photosynthetic pigments (chlorophyll $a, b$, total chlorophylls and carotenoids) and its products (glucose, sucrose and total soluble sugars). Various vegetative growth parameters were also analyzed to correlate and confirm our results like \% germination, root and shoot lengths, leaf area and relative water content. C. lancifolius was found not only an efficient, eco-friendly and cost-effective biosorbent for heavy metal copper but it is also an effective fertilizer too.

Keywords: $\quad$ *Address of Correspondence:

Conocarpus lancifolius, Copper, Biosorption, Shabana.askari@yahoo.com

Photosynthetic pigments, Cicer arietinum.
Article info.

Received: March 15, 2018

Accepted: June 25, 2018
Cite this article: Askari S, Khurshid H. Conocarpus mediated improvement in photosynthetic pigments of Cicer arietinum growing under copper stress. RADS J. Biol. Res. Appl. Sci. 2018; 9(1): 41-49.

This is an Open Access article distributed under the terms of the Creative Commons Attribution License (http://creativecommons.org/licenses/by/4.0), which permits unrestricted use, distribution, and reproduction in any medium, provided the original work is properly cited.

\section{INTRODUCTION}

Conocarpus lancifolius is commonly known for its unfriendly traits like the unpleasant smell, pollen allergy, and its roots can cause damage to walls. Chemical compounds which are present in $C$. lancifolius are Flavonoids, Saponins, and phenols ${ }^{1,2}$. The tree's wood is dense and suitable for charcoal. Goats use the young trees and shoots as fodder, although the leaves contain tannin ${ }^{3}$. Because of its high salt tolerance and relative drought tolerance, the tree is sometimes planted as a pioneer species in reforestation projects in its native habitat. Copper toxicity has become a threat to both agricultural and environmental concerns. Usual sources of Copper contamination in agricultural soil include industrial effluents, agricultural wastes, and the use of agrochemicals like insecticides, fungicides, and pesticides. Copper is present in many forms in soils, with free $\mathrm{Cu}^{2+}$ activity considered to be the best indicator of phytoavailability ${ }^{4}$. Adsorption of $\mathrm{Cu}$ is highly $\mathrm{pH}$ dependent and phytoavailability of $\mathrm{Cu}$ increases with decreasing $\mathrm{pH}^{5}$. Soluble $\mathrm{Cu}$ accounts for only a very small proportion of the total amount in the soil. Copper has a high affinity for solid phase organic matter, and is 
therefore not readily leached and can accumulate in the surface soil6,7. Copper is an essential micronutrient but exposure to excess $\mathrm{Cu}$ has a detrimental effect on plant growth leading to cellular damage of plants ${ }^{2,8,9}$. This leads to the inactivation of biomolecules by blocking essential functional groups or by displacing the essential metal ions ${ }^{10}$. The effect of $\mathrm{Cu}$ toxicity is largely on root growth and morphology. Copper tends to accumulate in the root tissue with little translocation to the shoots ${ }^{11}$. It can kill bacteria, algae, plants, snails, and fungi 12 .

The current research was based on the question that could Conocarpus lancifolius improve the photosynthesis in Cicer arietinum growing under copper stress?

\section{MATERIALS AND METHODS}

Good quality seeds of Cicer arietinum were purchased from local market, healthy seeds were selected and were surface sterilized. Total 27 soil bags were prepared each provided with $1 \mathrm{~kg}$ of garden soil. Among them, 3were marked as control supplied with only distilled water.12 soil bags (triplicates of each $\mathrm{Cu}$ concentration ie., 25ppm, 50ppm, 75ppm, 100ppm) were marked as experimental plants.12 soil bags (triplicates of each $\mathrm{Cu}$ concentration) were marked as treated plants, also supplied with 5 $\mathrm{gm} / \mathrm{Kg}$ of Conocarpus lancifolius powder as a biosorbent. Seeds were carefully sown (6 seeds/soil bag). After 20 days of sowing physical parameters like percent germination root, shoot length, leaf area, and relative water content was observed. Biochemical tests on the subject of chlorophyll contents were performed by ${ }^{13}$ and ${ }^{14}$ method, carotenoids by ${ }^{15}$, protein contents by ${ }^{16}$ and glucose, sucrose, total soluble sugars by ${ }^{17}$ were estimated.

\section{RESULTS}

The current research was designed to evaluate the capabilities of Conocarpus lancifolius on photosynthetic pigments of Cicer arietinum growing under copper stress. Along with photosynthetic pigments, several other biophysical and biochemical parameters were analyzed, which are given below.

\section{Rate of germination}

The rate of germination of Cicer arietinum was found to be $44,48,34$ and $35 \%$ respectively growing under copper amended soil, whereas it was $40 \%$ in control plants. Low concentrations of copper are thought to be beneficial to plants ${ }^{18}$, that is why the rate of germination was found to be increased Table 1. Adverse effects were found on the rate of germination of Cicer arietinum at higher concentrations of copper (75 \& 100 ppm), which may attribute to the augmentation of protease activity and reduced amylase activities ${ }^{19-23}$. Increased proteases catabolize proteins whereas decreased amylase activity reduced hydrolysis of starch which is necessary for energy supply to developing embryos, this may be the reason for inhibition of seed germination at high concentrations of Copper. Conocarpus lancifolius did not show an efficient improvement on the rate of germination of Cicer arietinum under copper stress and found to be $30,33,35$ and $42 \%$ at all supplied levels of copper, which may attribute to the oxidation of phenolic compounds present in it ${ }^{24}$. Copper is an essential micronutrient required in a small amount and has a high affinity for solid phase organic matter, and may be accumulated on the surface of Conocarpus lancifolius ${ }^{25,7}$.

Table 1: Effect of $\mathrm{Cu}$ and its biosorption by Conocarpus lancifolius on the rate of germination (\%) of Cicer arietinum L.

\begin{tabular}{|c|c|c|c|c|}
\hline \# & $\begin{array}{c}\mathrm{Cu} \\
\text { (ppm) }\end{array}$ & $\begin{array}{l}\text { Control } \\
\text { plants }\end{array}$ & $\begin{array}{c}\text { Experimental } \\
\text { plants }\end{array}$ & $\begin{array}{l}\text { Treated } \\
\text { plants }\end{array}$ \\
\hline 1 & 0 & 40 & - & - \\
\hline 2 & 25 & - & 44 & 30 \\
\hline 3 & 50 & - & 45 & 33 \\
\hline 4 & 75 & - & 38 & 35 \\
\hline 5 & 100 & - & 35 & 42 \\
\hline
\end{tabular}




\section{Shoot length}

Data presented in Table 2 showed drastic effects of copper on shoot length of Cicer arietinum and reduction was recorded up to $8.87 \pm 1.99,9.33 \pm 2.46,7.83 \pm 2.88$, $8.31 \pm 2.78$ respectively at all applied concentration of copper, whereas it was $9.63 \pm 0.80 \mathrm{~cm}$ in control. Shortening in shoot length due to toxic metal copper was also found by many previous workers ${ }^{26-28}$ may attribute to the affinity of heavy metal copper for biomolecules like carboxyl, sulfhydryl, phosphate, amide and amine groups that may cause cell wall loosening and in turn inhibition in mitosis ${ }^{29}$. Reduction in shoot length may also be attributed to the poor root system because toxic metals first enter root tissues, persist there and cause drastic effects ${ }^{20,7}$ and thus overall plant growth may be affected. Significant improvement was carried out by the application of Conocarpus lancifolius leaves in shoot length of Cicer arietinum plants up to $9.73 \pm 0.68$, $10.66 \pm 0.75,11.67 \pm 1.52$ and $10.83 \pm 1.52 \mathrm{~cm}$. Functional groups like ketone group, carboxylate groups, Hydroxyl group, Hydrocarbon, Amines, and Carbon oxygen group 30 present in Conocarpus lancifolius is negatively charged and behaves as an active ligand for positively charged salt ions like copper. According to the present study, Conocarpus lancifolius was found to be an effective biosorbent and an efficient fertilizer for the growth of plants $^{31-33}$.

\section{Root length:}

Data of present study revealed drastic effects of copper in root length of Cicer arietinum up to $25.27 \pm 8.5,18.9 \pm 1.2$, $23.7 \pm 3.2,19.7 \pm 2.5 \mathrm{~cm}$ respectively whereas in control it was $25.5 \pm 7.15 \mathrm{~cm}$. Copper at 25ppm does not show toxic effects on root length of Cicer arietinum ${ }^{2}$ may attribute to the beneficial concentration as it is essential micronutrient for the plant. According to literature surveyed heavy metals have great affinity for proteins and lipids and plasma membrane which is composed of proteins and phospholipids is the first which combat with toxic metal copper $^{34}$ and increased potassium efflux by high concentration of $\mathrm{Cu}$ from roots of various plants such as wheat was noticed earlier ${ }^{35}$ from where disturbance started and the growth was badly affected. Disturbance in process of mitosis due to the high concentration of Copper may also be the reason of reduction in root length of $C$. arietinum at all applied levels of copper (Table 2). It is being observed that healthy roots play a key role in the virtuous growth of plants, but in a contaminated environment usually roots are first which face contaminations and try to retain contaminants like heavy metals and preventing them to reach in the shoot and any flaw or deformity due to $\mathrm{Cu}$ toxicity in roots causes stunted growth of plant ${ }^{20}$. Significant improvement was exhibited by the application of $C$. lancifolius in root length of $C$. arietinum up to $28.8 \pm 1.18, \quad 30.23 \pm 3.81$, $29.01 \pm 10.93$ and $37.56 \pm 3.78 \mathrm{~cm}$ over control (Table 2). C. lancifolius not only biosorbed the copper efficiently and improved root elongation significantly but it also provided several macro and micronutrients to the plants that are why root length increased as compared to control.

\section{Leaf area:}

Leaf area of Cicer arietinum growing under copper amended soil was found to be $0.26 \pm 0.07,0.20 \pm 0.06$, $0.15 \pm 0.04, \quad 0.23 \pm 0.23$ respectively at all applied concentrations, whereas it was $0.27 \pm 0.28 \mathrm{~cm}^{2}$ in control plants (Table 2). Adverse effects of heavy metal copper exhibited on reduced leaf area of $C$. arietinum may attribute to the damaged root system (Table 2) or may be due to injured plasma membrane which caused inhibition in the conduction of water and mineral ions, leaf area reduced to overcome these stresses and to regulate a rate of transpiration. High concentrations of toxic metal Copper destroyed the mitochondrial structure in the plants and so their energy-producing activities were damaged ${ }^{36}$. C. lancifolius supplied plants showed a significant improvement in the leaf area of $C$. arietinum up to $0.30 \pm 0.03,0.38 \pm 0.04,0.35 \pm 2.09,0.26 \pm 0.03$ respectively at all applied levels of toxic metal copper. According to the data presented in Table 2, C. lancifolius efficiently biosorbed toxic metal copper and effectively enhanced leaf area by providing macronutrients and micronutrients present in them. 
Table 2: Effect of $C$. lancifolius on shoot length, root length and leaf area of $C$. arietinum $L$. growing under copper stress.

\begin{tabular}{cccccccc}
\hline & \multicolumn{3}{c}{ SHOOT LENGTH $(\mathbf{c m})$} & \multicolumn{2}{c}{ ROOT LENGTH $(\mathbf{c m})$} & \multicolumn{2}{c}{ LEAF AREA $\left(\mathbf{c m}^{2}\right)$} \\
\hline S.\# & Cu[ppm] & Experimental & Treated & Experimental & Treated & Experimental & Treated \\
\hline 1 & 0 & $9.63 \pm 0.80$ & $9.63 \pm 0.80$ & $25.5 \pm 7.15$ & $25.5 \pm 7.15$ & $0.27 \pm 0.28$ & $0.27 \pm 0.28$ \\
\hline 2 & 25 & $8.87 \pm 1.99$ & $9.73 \pm 0.68$ & $25.27 \pm 8.5$ & $28.8 \pm 1.18$ & $0.26 \pm 0.07$ & $0.30 \pm 0.03$ \\
\hline 3 & 50 & $9.33 \pm 2.46$ & $10.66 \pm 0.75$ & $18.9 \pm 1.2$ & $30.23 \pm 3.81$ & $0.20 \pm 0.06$ & $0.38 \pm 0.04$ \\
\hline 4 & 75 & $7.83 \pm 2.88$ & $11.67 \pm 1.52$ & $23.7 \pm 3.2$ & $29.01 \pm 10.9$ & $0.15 \pm 0.0 .4$ & $0.35 \pm 2.09$ \\
\hline 5 & 100 & $8.31 \pm 2.78$ & $10.83 \pm 1.52$ & $19.7 \pm 2.5$ & $37.56 \pm 3.78$ & $0.23 \pm 0.23$ & $0.26 \pm 0.03$ \\
\hline \multicolumn{7}{l}{ Results expressed as Mean \pm SEM of triplicate. } \\
\hline
\end{tabular}

\section{Biomass:}

Drastic effects of copper were found on biomass of Cicer arietinum up to $0.48 \pm 0.39, \quad 0.66 \pm 0.12, \quad 0.76 \pm 0.114$, $0.69 \pm 0.26$ gm respectively at all applied concentrations of copper whereas it was $0.85 \pm 0.203 \mathrm{gm}$ in control. Literature surveyed reveals the adverse effects of varying concentrations of copper in various plants like Cicer arietinum and wheat $^{37}$. Salt enters plant with water through osmosis where it accumulates and stops various physiological functions by replacing some essential ions from enzymes and proteins ${ }^{38}$ reduction in different growth parameters including root length, shoot length, leaf area and biomass may attribute to the osmotic injury and specific ions toxicity caused by copper ${ }^{39-41}$. Reduction in biomass of Cicer arietinum growing under all applied concentrations of copper supports the data presented in Table 2, because the reduction in root length may cause inhibition in the conduction of water and minerals whereas inhibition in leaf area may cause deleterious effects on photosynthesis, which somehow or the other cause decline in biomass of Cicer arietinum. Application of magical powder of Conocarpus lancifolius leaves showed considerable improvement in biomass of Cicer arietinum up to $0.49 \pm 0.35,0.64 \pm 0.11,0.79 \pm 0.11$ and $0.8 \pm 0.27 \mathrm{gm}$ at all applied levels of copper. Conocarpus specie provided macromolecules like carbohydrates, lipids, and proteins which somehow or the other make complex molecules or ligands with copper and cleaned the plant environment. Conocarpus lancifolius leaves not only biosorb copper but also provided macro and micronutrients ${ }^{54}$ to $C$. arietinum which enhanced plants overall growth.

\section{Relative water content (R.W.C):}

Effect of Copper on the relative water content of Cicer arietinum mentioned in Table 2 was deadly and exhibited a decrease up to $39.4 \pm 5.35,35.5 \pm 8.21,11.83 \pm 9.54$ and $20.5 \pm 18.5 \%$ respectively at all applied levels of copper whereas it was $41.67 \pm 2.9 \%$ in control.

Inhibition in the relative water content of Cicer arietinum confirmed the results presented in Table 1 because conduction of water reduced due to the damaged root system and hence decreased relative water content which ultimately declined leaf area just to regulate the rate of transpiration ${ }^{42}$. Relative water content is a stress indicator which exhibited the status of plant growth regarding root/shoot length, leaf area, biomass and other physiological functions like photosynthesis. Literature surveyed revealed that under heavy metal stress the water transport in plant reduced and resulted in water deficit in the plants ${ }^{43,44}$. Application of Conocarpus lancifolius significantly improved the relative water content of Cicer arietinum up to $43.6 \pm 4.7,47.76 \pm 13.5$, $36.67 \pm 18.5$ and $31.6 \pm 4.14 \%$ at all supplied concentrations of copper Table 2. Biosorption of copper by Conocarpus depends on the relative amount of toxic metal ions and biosorbent 30 . 
Table 3: Effect of Copper and its biosorption by C. lancifoliuson biomass (gm) and relative water contents (\%) of Cicer arietinum.

\begin{tabular}{cccccc}
\hline \multicolumn{5}{c}{ BIOMASS (gm) } & \multicolumn{2}{c}{ R.W.C (\%) } \\
\hline S. No. & $\mathrm{Cu}[\mathrm{ppm}]$ & Experimental & Treated & Experimental & Treated \\
\hline 1 & 0 & $0.85 \pm 0.203$ & $0.85 \pm 0.203$ & $41.67 \pm 2.9$ & $41.67 \pm 2.9$ \\
\hline 2 & 25 & $0.48 \pm 0.39$ & $0.49 \pm 0.35$ & $39.4 \pm 5.35$ & $43.6 \pm 4.7$ \\
\hline 3 & 50 & $0.66 \pm 0.12$ & $0.64 \pm 0.11$ & $35.5 \pm 8.21$ & $47.76 \pm 13.5$ \\
\hline 4 & 75 & $0.76 \pm 0.114$ & $0.79 \pm 0.11$ & $11.83 \pm 9.54$ & $36.67 \pm 18.5$ \\
\hline 5 & 100 & $0.69 \pm 0.26$ & $0.78 \pm 0.27$ & $20.5 \pm 18.5$ & $31.6 \pm 4.14$ \\
\hline \multicolumn{7}{l}{ Results expressed as Mean \pm SEM of triplicate. } \\
\hline
\end{tabular}

\section{Photosynthetic pigments}

\section{Chlorophyll 'A'}

Current data revealed that toxicity of copper imposed a deleterious effect on chlorophyll a of Cicer arietinum. Reduction in chlorophyll an of Cicer arietinum was found to be $0.725 \pm 0.06,0.647 \pm 0.10,0.784 \pm 0.02,0.7159 \pm 0.07$ at all supplied concentrations of copper respectively, whereas it was $0.8726 \pm 0.43 \mathrm{mg} / \mathrm{gm}$ F.wt in control leaves (Table 4). Reduction in chlorophyll a may attribute to the decline in volume and number of Mesophyll chloroplasts of Cicer arietinum leaves growing under $\mathrm{Cu}$ stress ${ }^{20}$. Several reports showed chlorophyll biosynthesis inhibition by metals in higher plants ${ }^{45-48}$. Heavy metal Copper replaced magnesium of porphyrin ring of chlorophyll due to which leaf remain green but nonfunctional hence inhibited process of photosynthesis ${ }^{45,49}$. A significant improvement in chlorophyll a of Cicer arietinum leaves was noted in Conocarpus lancifolius supplied plants up to $0.738 \pm 0.02,0.846 \pm 0.10,0.798 \pm 0.01$ and $0.7488 \pm 0.10$ $\mathrm{mg} / \mathrm{gm}$ F.wt, this may attribute to the ligand forming capability of macromolecules of Conocarpus lancifolius which is a salt-tolerant species ${ }^{50-52}$ and contribution of its micronutrients as effective fertilizer to the Cicer arietinum. Moreover Copper has a high affinity for the solid phase organic matter, which can accumulate on the surface of Conocarpus lancifolius ${ }^{7,25}$.

\section{Chlorophyll 'B'}

Deleterious effects of Copper were found on chlorophyll 'b' of Cicer arietinum up to $0.1942 \pm 0.003,0.1557 \pm 0.002$, $0.323 \pm 0.002$ and $0.292 \pm 0.01 \mathrm{mg} / \mathrm{gm}$ f.wt at all applied concentrations of copper respectively, whereas it was $0.245 \pm 0.01 \mathrm{mg} / \mathrm{gm}$ f.wt. in control plants (Table 4). High concentration of copper may deform chloroplast by replacing $\mathrm{Mg}$ and consequently lead to disruption of photosynthetic machinery Table 320,45,48,49. Cu imposed adverse effects on Cicer arietinum may attribute to the redox behavior of the metal, which leads to the exacerbate formation of reactive oxygen species, inducing to severe damage such as biological membrane degradation and protein denaturation ${ }^{7}$.

Conocarpus lancifolius supplied plants showed noteworthy improvement in Cicer arietinum up to $0.282 \pm 0.009,0.315 \pm 0.001,0.279 \pm 0.002$ and $0.27 \pm 0.01$ $\mathrm{mg} / \mathrm{gm}$ f.wt may attribute to the high efficiency of metal binding to free sites present in Conocarpus lancifolius.

\section{Total chlorophyll}

Adverse effects of copper were found on total chlorophyll up to $0.918 \pm 0.06,1.02 \pm 0.01,0.803 \pm 0.35$ and $1.08 \pm 0.05$ in Cicer arietinum leave growing under applied levels of copper respectively. Whereas it was $1.11825 \pm 0.01$ $\mathrm{mg} / \mathrm{gm}$ f.wt in control (Table 4). Copper is an important micronutrient that regulates vital physiological functions of plants as a catalyzer of redox reaction in mitochondria, chloroplasts, and cytoplasm of cells ${ }^{53}$ or as an electron carrier during plant respiration ${ }^{54}$. However, at higher concentrations, Copper becomes lethal to plant tissues ${ }^{40}$ and inhibit drastically all physiological functions as it has a great affinity for proteins, enzymes and porphyrin ring of chlorophyll155. Cu was shown to inhibit growth and to interfere with important cellular processes such as photosynthesis and respiration ${ }^{56}$. The present study 
showed an improvement in total chlorophyll contents of Conocarpus lancifolius treated plants up to $1.02 \pm 0.01$, $1.162 \pm 0.01,1.069 \pm 0.0$ and $1.019 \pm 0.015$ at all supplied levels of copper. The data suggested that Conocarpus lancifolius is provided with an efficient mechanism against stress which is not only low cost, easily and abundantly available but also eco-friendly biosorbent.
Application of C. lancifolius significantly detoxified Cicer arietinum by toxic copper as $19.18 \pm 0.11,38.62 \pm 16.3$, $71.67 \pm 2.2$ and $24.01 \pm 28.84 \mathrm{mg} / \mathrm{gm}$ f.wt. Conocarpus lancifolius efficiently detoxify the effects of copper and enhanced synthesis of glucose via photosynthesis ${ }^{58}$, (Table 4 \& 5).

Table 4: Effect of $C$. lancifolius on photosynthetic pigments of $C$. arietinum growing under copper stress (mg/gm F.wt).

\begin{tabular}{ccccccccc}
\hline & \multicolumn{2}{c}{ Chlorophyll a } & \multicolumn{2}{c}{ Chlorophyll b } & \multicolumn{2}{c}{ Total chlorophyll } & \multicolumn{2}{c}{ Carotenoid } \\
\hline Cu[ppm] & Experimental & Treated & Experimental & Treated & Experimental & Treated & Experimental & Treated \\
\hline 0 & $0.873 \pm 0.43$ & $0.873 \pm 0.43$ & $0.245 \pm 0.01$ & $0.245 \pm 0.01$ & $1.118 \pm 0.01$ & $1.118 \pm 0.01$ & $0.605 \pm 0.001$ & $0.605 \pm 0.001$ \\
\hline 25 & $0.725 \pm 0.06$ & $0.738 \pm 0.02$ & $0.194 \pm 0.003$ & $0.282 \pm 0.009$ & $0.918 \pm 0.06$ & $1.02 \pm 0.01$ & $0.47 \pm 0.01$ & $0.629 \pm 1.19$ \\
\hline 50 & $0.647 \pm 0.10$ & $0.846 \pm 0.10$ & $0.1557 \pm 0.002$ & $0.315 \pm 0.001$ & $1.02 \pm 0.01$ & $1.162 \pm 0.01$ & $0.422 \pm 0.01$ & $1.191 \pm 0.025$ \\
\hline 75 & $0.784 \pm 0.02$ & $0.798 \pm 0.01$ & $0.323 \pm 0.002$ & $0.279 \pm 0.002$ & $0.803 \pm 0.35$ & $1.069 \pm 0.02$ & $0.56 \pm 0.02$ & $0.667 \pm 0.02$ \\
\hline 100 & $0.7159 \pm 0.07$ & $0.7488 \pm 0.10$ & $0.292 \pm 0.01$ & $0.27 \pm 0.01$ & $1.08 \pm 0.05$ & $1.019 \pm 0.015$ & $0.563 \pm 0.01$ & $0.659 \pm 0.025$ \\
\hline
\end{tabular}

Results expressed as Mean \pm SEM of triplicate.

\section{Photosynthetic products}

\section{Glucose:}

Current data revealed drastic reductions in glucose contents of Cicer arietinum growing in copper amended soil and found to be $14.28 \pm 4.3,29 \pm 36.13,26.8 \pm 13.37$ and $8.38 \pm 4.74$ at all applied levels of copper respectively. Glucose content of control was found to be $16.64 \pm 13.55$ $\mathrm{mg} / \mathrm{gm}$ f.wt (Table 5). Copper as a micronutrient involved in various physiological functions of the plant as a catalyzer ${ }^{53}$ or as an electron carrier ${ }^{54}$, but present data showed a reduction in glucose even at 25ppm copper, which proved the results of Table 3 , where chlorophyll a \& $\mathrm{b}$ and total chlorophyll reduced. Reduction in glucose may attribute to the polymerization of glucose to sucrose (Table 4). At higher concentrations, copper became toxic and replaced magnesium from porphyrin ring of chlorophyll, made it non-functional and distorted and hence chlorophyll reduced (Table 3). Due to destroyed photosynthesis (in order to produce glucose for glycolysis) polymerized sucrose molecules broke down which ultimately increased glucose and decreased sucrose molecules $(50 \& 75 p p m)^{45,54,55,57}$. Glucose and sucrose were badly affected at 100ppm copper in Cicer arietinum.

\section{Sucrose:}

Current data revealed the deleterious effects of copper on Sucrose of Cicer arietinum to be $149.6 \pm 2.3,94.4 \pm 1.4$, $70.42 \pm 10.1$ and $40.93 \pm 50.6$ whereas it was $71.14 \pm 5.28$ $\mathrm{mg} / \mathrm{gm}$ f.wt. in control. Reduction in chlorophyll (Table 3) induced a decrease in photosynthesis hence created stress in the plant body. Higher sucrose accumulation in damaged leaves may result both in the higher resistance of their photosynthetic apparatus ${ }^{59}$. The negative effect of heavy metals on carbon metabolism is a result of their possible interaction with the reactive center of ribulose biphosphate carboxylase ${ }^{60}$. Inhibition in sucrose at higher concentrations (75 \& 100ppm) indicates that Copper acts as negative biocatalyst and inhibits or slows down the processes of polymerization ${ }^{57}$.

Application of Conocarpus lancifolius showed the enhanced effect on sucrose of Cicer arietinum up to $90.43 \pm 33.08,67.1 \pm 14.5,105.96 \pm 33.7$ and $42.27 \pm 11.5$. The Conocarpus lancifolius not only efficiently biosorbed copper from Cicer arietinumbut also provided its macro and micronutrients for better plant growth. 
Table 5: Effect of $C$. lancifolius on photosynthetic products of Cicer arietinum growing under copper stress.

\begin{tabular}{|c|c|c|c|c|c|c|c|}
\hline \multirow[b]{2}{*}{ S.\# } & \multirow[b]{2}{*}{$\mathrm{Cu}[\mathrm{ppm}]$} & \multicolumn{2}{|c|}{ GLUCOSE } & \multicolumn{2}{|c|}{ SUCROSE } & \multicolumn{2}{|c|}{ TOTAL SOLUBLE SUGAR } \\
\hline & & Experimental & Treated & Experimental & Treated & Experimental & Treated \\
\hline 1 & 0 & $16.64 \pm 13.55$ & $16.64 \pm 13$ & $71.14 \pm 5.3$ & $71.14 \pm 5.3$ & $117.43 \pm 16.9$ & $117.43 \pm 16.9$ \\
\hline 2 & 25 & $14.28 \pm 4.3$ & $19.18 \pm 0.1$ & $149.6 \pm 2.3$ & $90.43 \pm 33$ & $62.73 \pm 1.17$ & $91.88 \pm 34.6$ \\
\hline 3 & 50 & $29 \pm 36.13$ & $38.62 \pm 16$ & $94.4 \pm 1.4$ & $67.1 \pm 14.5$ & $100.2 \pm 3.305$ & $134.13 \pm 1.19$ \\
\hline 4 & 75 & $26.8 \pm 13.37$ & $71.67 \pm 2.2$ & $70.42 \pm 10.1$ & $106 \pm 33$ & $82.43 \pm 2.28$ & $108 \pm 3.72$ \\
\hline 5 & 100 & $8.38 \pm 4.74$ & $24.01 \pm 29$ & $40.93 \pm 50.6$ & $42.27 \pm 12$ & $97.53 \pm 3.69$ & $103.5 \pm 22.39$ \\
\hline
\end{tabular}

\section{Total soluble sugars:}

Sugars considered as the main source of energy to operate all physiological functions of the plant. Current data revealed the drastic effects of copper on total soluble sugars of Cicer arietinum up to $62.73 \pm 1.17,100.2 \pm 3.305$, $82.43 \pm 2.28$, and $97.53 \pm 3.69$ whereas it was $117.43 \pm 16.9$ $\mathrm{mg} / \mathrm{gm}$ f.wt., in control (Table 4). A vital role of soluble sugars (reducing and non reducing) including sucrose, glucose, and fructose, is evident in plant structure and metabolism. In addition to the role of sugars in osmoregulation, the soluble sugars allow the plants to maximize sufficient carbohydrates storage reserves to support basal metabolism under the stressed environment ${ }^{61}$. However high light irradiance, heavy metals, nutrient shortage and ozone decreased soluble sugar concentrations ${ }^{62}$. Deleterious effects of copper on total soluble sugars of Cicer arietinum may attribute to the reduction in the number of chlorophyll contents (Table 3 ). Application of Conocarpus lancifolius significantly biosorbed copper and enhanced total soluble sugars in Cicer arietinum up to $91.88 \pm 34.6,134.13 \pm 1.19$, $108 \pm 3.72, \quad 103.5 \pm 22.39 \mathrm{mg} / \mathrm{gm}$ f.wt ${ }^{63}$. Conocarpus lancifoliusare negatively charged and behaves as an active ligand for positively charged salt ions like copper ${ }^{30}$.

\section{CONCLUSIONS}

As heavy metal contamination has become a universal threat to life, these toxic metals have to be eliminated from the soil through some procedure which should be cost-effective and eco-friendly. Current research work was designed to investigate the efficiency of Conocarpus lancefolius for the biosorption of copper from Cicer arietinum. Results of the present study showed that biosorbent C. lancefolius not only actively biosorbed heavy metal copper but also provide macro and micronutrients and enhanced plant's growth. C. lancefolius was found an efficient, easily available and eco-friendly biosorbent which should be investigated for other important crops for biosorption of other heavy metals. Apart from this, laborious literature survey revealed that Conocarpus lancifolius is an antifungal and antibacterial plant and may use in reducing bacterial and fungal contaminations.

\section{REFERENCES}

1. Trease GE, Evans WC. Pharmacognosy. 13th ed. London, Bailliere Tindall. 1989; $p 833$.

2. Al-Surrayai T, Yateem A, Al-Kandari R, Al-Sharrah T, Bin-Haji A. The use of Conocarpus lancifolius trees for the remediation of oil-contaminated soils. Soil \& Sed Contam. 2009; 18(3):354-68.

3. Redha A, Patrice S, Al-Hasan R, Afzal M. Conocarpus lancifolius biochemical responses to variable UV-B irradiation. Biochem system ecol. 2013; 48:157-62.

4. Sauvé S, Cook N, Hendershot WH, McBride MB. Linking plant tissue concentrations and soil copper pools in urban contaminated soils. Environ poll. 1996; 94(2):153-7.

5. Tye AM, Young S, Crout NM, Zhang H, Preston S, Zhao FJ, McGrath SP. Speciation and solubility of $\mathrm{Cu}$, $\mathrm{Ni}$, and $\mathrm{Pb}$ in contaminated soils. Euro J S Sci. 2004; 55(3):579-90.

6. McBride M, Sauve S, Hendershot W. Solubility control of $\mathrm{Cu}, \mathrm{Zn}, \mathrm{Cd}$, and $\mathrm{Pb}$ in contaminated soils. Euro J S Sci. 1997; 48(2):337-46.

7. Emamverdian A, Ding $Y$, Mokhberdoran F, Xie $Y$. Heavy metal stress and some mechanisms of plant defense response. T Sci World J. 2015. 
8. Gaetke LM, Chow CK. Copper toxicity, oxidative stress, and antioxidant nutrients. Toxico. 2003; 189(12):147-63.

9. Hall JL. Cellular mechanisms for heavy metal detoxification and tolerance. J Experi bot. 2002; 53(366):1-1.

10. Goyer RA, Clarkson TW. Toxic effects of metals. Casarett \& Doull's Toxicology. The Basic Science of Poisons, Fifth Edition, Klaassen, CD [Ed]. McGrawHill Health Professions Division, ISBN. 1996.

11. Marschner H. Mineral Nutrition of Higher Plants, 2nd ed., Academic Press, London, 1995.

12. Sweet DV. Registry of Toxic Effects of Chemical Substances (RTECS), 1986 edition. User's guide to the rtecs computer tape. National Inst. for Occupational Safety and Health, Cincinnati, $\mathrm{OH}$ (USA); 1987.

13. Arnon DI. Copper enzymes in isolated chloroplasts. Polyphenoloxidase in Beta vulgaris. Plant Physiol. 1949 (1):1.

14. Macknney G. Absorption of light by chlorophyll solutions. J. Biol. Chem. 1941; 140:315-22.

15. Kirk JT, Allen RL. Dependence of chloroplast pigment synthesis on protein synthesis: effect of actidione. Biochem Biophys Res commun. 1965; 21(6):523-30.

16. Lowry $\mathrm{OH}$, Rosebrough NJ, Farr AL. Randall, RJ. Protein measure- ment with the Folin phenol reagent. J Biol. Chem. 1951; 193:265-275.

17. Razi A, Matruda K, Arslan A. Water stress induced changes in the concentration of proline and other solutes in growing regions. J Experi Bot. 1985; 36(1):1716-25.

18. Gad N. Role and importance of cobalt nutrition on groundnut (Arachis hypogaea) production. World Appl Sci J. 2012; 20(3):359-67.

19. Ashagre H, Almaw D, Feyisa T. Effect of copper and zinc on seed germination, phytotoxicity, tolerance and seedling vigor of tomato (Lycopersicon esculentum $L$. cultivar Roma VF). Intern J Agri Sci Res. 2013; 2(11):312-7.

20. Panou-Filotheou $\mathrm{H}$, Bosabalidis AM, Karataglis S. Effects of copper toxicity on leaves of oregano (Origanum vulgare subsp. hirtum). Annals of Botany. 2001; 88(2):207-14.

21. Verma JP, Singh V, Yadav J. Effect of copper sulphate on seed germination, plant growth and peroxidase activity of Mung bean (Vigna radiata). Int. J. Bot. 2011;7(2):200-4.

22. Zeid IM. Responses of Phaseolus vulgaris chromium and cobalt treatments. Biol Plant. 2001; 44(1):111-5.

23. Parmar NG, Vithalani SD, Chanda SV. Alteration in growth and peroxidase activity by heavy metals in Phaseolus seedlings. Acta Physiol Plant. 2002; 24(1):89-95.

24. Medda S, Mondal NK. Chromium toxicity and ultrastructural deformation of Cicer arietinum with special reference of root elongation and coleoptile growth. Ann Agr Sci. 2017; 15(3):396-401.

25. McBride M, Sauve S, Hendershot W. Solubility control of $\mathrm{Cu}, \mathrm{Zn}, \mathrm{Cd}$, and $\mathrm{Pb}$ in contaminated soils. European Journal of Soil Science. 1997; 48(2):33746.

26. Karataglis S, Babalonas D. The toxic effects of copper on the growth of Solanum lycopersicum $L$. collected from $\mathrm{Zn}$-and Pb-soil. Angewandte Botanik (Germany, FR). 1985.

27. Lidon FC, Henriques FS. Effects of copper on the nitrate to ammonia reduction mechanism in rice plants. Photosynthetica-Praha-. 1992; 26:371-380.

28. Moustakas M, Ouzounidou G, Symeonidis L, Karataglis S. Field study of the effects of excess copper on wheat photosynthesis and productivity. Soil sci plant nutri. 1997; 43(3):531-9.

29. Goyer RA, Clarkson TW. Toxic effects of metals. Casarett \& Doull's Toxicology. The Basic Science of Poisons, Fifth Edition, Klaassen, CD [Ed]. McGrawHill Health Professions Division, ISBN. 1996.

30. Altameemi I.A., Thuraya. M.A, and Nasser T. A NEW SimPle METHOD FOR THE TREATMENT OF WASTEWATER CONTAINING CU (II) AND ZN(II) IONS USING ADSORPTION ON DRIED CONOCARPUS ERECTUS LEAVES. Journal of Basrah Researchers (Sciences). 2013; 39(2): 125-36.

31. Ashraf M, Nawazish S, Athar HU. Are chlorophyll fluorescence and photosynthetic capacity potential physiological determinants of drought tolerance in maize (Zea mays L.). Pak J Bot. 2007 ;39(4):1123-31.

32. Hussein MM, Shaaban MM, El-Saady AK. The response of cowpea plants grown under salinity stress to PK-foliar applications. Ame J Plant Physiol. 2010; 5(2):102-9.

33. Gunes A, Cicek N, Inal A, Alpaslan M, Eraslan F, Guneri E, Guzelordu T. Genotypic response of chickpea (Cicer arietinum L.) cultivars to drought stress implemented at pre-and post-anthesis stages and its relations with nutrient uptake and efficiency. Plant Soil Environ. 2006; 52(8):368.

34. Hall JL. Cellular mechanisms for heavy metal detoxification and tolerance. J Experi Bot. 2002; 53(366):1-1.

35. Quartacci MF, Cosi E, Navari-Izzo F. Lipids and NADPH-dependent superoxide production in plasma membrane vesicles from roots of wheat grown under copper deficiency or excess. J Experi Bot. 2001; 52(354):77-84.

36. Rout GR, Das P. Effect of metal toxicity on plant growth and metabolism: I. Zinc. InSustainable Agriculture 2009 (pp. 873-884). Springer, Dordrecht.

37. Solanki R, Dhankhar R. Biochemical changes and adaptive strategies of plants under heavy metal stress. Biologia. $2011 ; 66(2): 195-204$. 
38. Munns R. Physiological processes limiting plant growth in saline soils: some dogmas and hypotheses. Plant, Cell Enviro. 1993 ;16(1):15-24.

39. Zengin FK, Munzuroglu O. Effects of some heavy metals on the content of chlorophyll, proline and some antioxidant chemicals in bean (Phaseolus vulgaris L.) seedlings. Acta Biologica Cracoviensia Series Botanica. 2005 ;47(2):157-64.

40. Lombardi L, Sebastiani L. Copper toxicity in Prunus cerasifera: growth and antioxidant enzymes responses of in vitro grown plants. Plant Sci. 2005; 168(3):797-802.

41. Maksymiec W. Effect of copper on cellular processes in higher plants. Photosynthetica. 1997; 34:321-342.

42. Rodríguez L. Growth, relative water content, transpiration and photosynthetic pigment content in coffee trees (Coffea arabica L.) growing at different sunlight regimes. Cultivos Tropicales. 2013; 22(4):3741.

43. Kastori R, Petrović M, Petrović N. Effect of excess lead, cadmium, copper, and zinc on water relations in sunflower. J Plant Nutri. 1992; 15(11):2427-39.

44. Chen LM, Lin CC, Kao CH. Copper toxicity in rice seedlings: changes in antioxidative enzyme activities, $\mathrm{H} 2 \mathrm{O} 2$ level, and cell wall peroxidase activity in roots. Botan Bull Acad Sinica. 2000; 41.

45. Askari S, Azmat R. Biosorption of Hg: II. Repairing of the epidermal layer of leaves through nutrients of seaweeds in $\mathrm{Hg}$ distorted seedlings of Cicer arietinum. Pak. J. Bot. 2013; 45(5):1721-7.

46. Prasad DD, Prasad AR. Effect of lead and mercury on chlorophyll synthesis in mung bean seedlings. Phytochem. 1987; 26(4):881-3

47. Eleftheriou AP, Karataglis S. Ultrastructural and morphological characteristics of cultivated wheat growing on copper-polluted fields. Botanica acta. 1989; 102(2):134-40.

48. Ouzounidou G, Eleftheriou EP, Karataglis S. Ecophysical and ultrastructural effects of copper in Thlaspi ochroleucum (Cruciferae). Cana J Bot. 1992; 70(5):947-57.

49. Azmat R, Askari S. Improvement in the bioenergetics system of plants under $\mathrm{Hg}$ stress environment via seaweeds. Pak. J. Bot. 2015; 47(3):851-8.

50. Ali B., Ali A., Ali H.H. Possibility of Using Conocarpus lancifolius Engl. in Remediation of Some Iraqi Soils Polluted by Crude Oil. Advan Bio Res. 2014; 5(1):185-90.

51. Ali B., Ali A. Resistance of Conocarpus lancifolius Engl. to different levels of salinity and water supply. J Agri Biol Sci 2014; 9(6): p. 211-5.
52. Shirazi MU, Khan MA, Ali M, Mujtaba SM, Mumtaz S, Ali M, Khanzada B, Halo MA, Rafique M, Shah JA, Jafri KA. Growth performance and nutrient contents of some salt tolerant multipurpose tree species growing under saline environment. Pak. J. Bot. 2006; 38(5):1381-8.

53. Fargasova A. Toxicity comparison of some possible toxic metals ( $\mathrm{Cd}, \mathrm{Cu}, \mathrm{Pb}, \mathrm{Se}, \mathrm{Zn}$ ) on young seedlings of Sinapis alba L. Plant Soil Environ. 2004; 50(1):338.

54. Yruela I. Copper in plants: acquisition, transport, and interactions. Funct Plant Biol. 2009; 36(5):409-30.

55. Askari S, Arif N., Naheed S. Abolition of heavy metal mercury by low cost domestic organic wastes from the Phaseolus vulgaris. J Pharma Phytochem. 2017; 6(4):1807-11.

56. Prasad MN, Freitas H. Removal of toxic metals from solution by leaf, stem and root phytomass of Quercus ilex L.(holly oak). Environ Poll. 2000; 110(2):277-83.

57. Graham RD. The distribution of copper and soluble carbohydrates in wheat plants grown at high and low levels of copper supply. J Plant Nutri and Soil Sci. 1980; 143(2):161-9.

58. El-Naggar AH, Alzhrani AK, Ahmad M, Usman AR, Mohan D, Ok YS, Al-Wabel MI. Preparation of activated and non-activated carbon from Conocarpus pruning waste as low-cost adsorbent for removal of heavy metal ions from aqueous solution. BioResources. 2015; 11(1):1092-107.

59. Prokopiev, E. Planting of industrial regions. Zemizdat, Sofia, Bulgaria. 1978; 207pp.

60. Stiborová $M$, Ditrichová $M$, BŘEzinová $A$. Effect of heavy metal ions on growth and biochemical characteristics of photosynthesis of barley and maize seedlings. Biol Plant. 1987; 29(6):453-467.

61. Dubey RS, Singh AK. Salinity induces accumulation of soluble sugars and alters the activity of sugar metabolizing enzymes in rice plants. Biol Plant. 1999; 42(2):233-9.

62. Strand A, Hurry V, Henkes S, Huner N, Gustafsson P, Gardeström P, Stitt M. Acclimation of Arabidopsis leaves developing at low temperatures. Increasing cytoplasmic volume accompanies increased activities of enzymes in the Calvin cycle and in the sucrosebiosynthesis pathway. PI Physiol. 1999; 119(4):138798.

63. De Carvalho RP, Freitas JR, De Sousa AM, Moreira RL, Pinheiro MV, Krambrock K. Biosorption of copper ions by dried leaves: chemical bonds and site symmetry. Hydrometallurgy. 2003; 71(1-2):277-83. 